
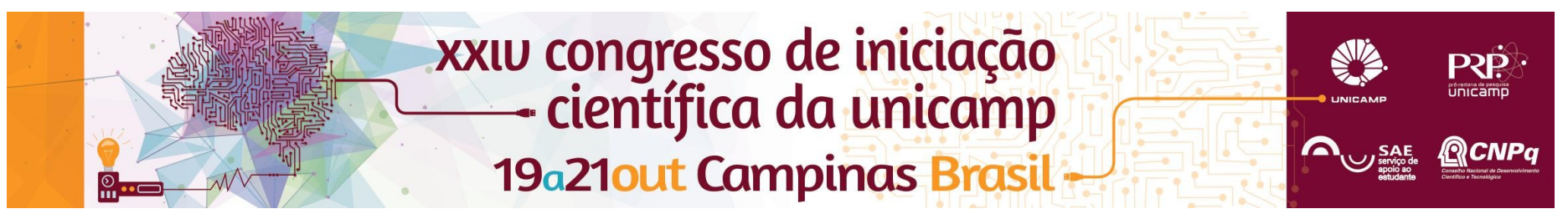

\title{
Controle e automação de um gaseificador de leito fluidizado
}

\section{Luís Felipe Lemes Batista Silva}

\section{Resumo}

O trabalho consiste em monitorar, controlar e automatizar uma planta de gaseificação através de um algorítimo criado na plataforma LabView que retornará gráficos de temperatura e pressão. Seu sistema de aquisição de dados é rápido, o que permite um acompanhamento em tempo real e controle de alimentação da maquina, assim optimizando o processo produtivo, a interface é de fácil manejo assim simplificando ao máximo o manuseio do equipamento.

\section{Palavras-chave \\ Controle e automação, gaseificador, leito fluidizado.}

\section{Introdução}

Tendo em vista o aumento da procura por fontes de energia limpa nas últimas décadas, a gaseificação surge como uma alternativa para reduzir os impactos naturais causados pelos combustíveis fosseis, pois possui uma baixa emissão de poluentes e o $\mathrm{CO} 2$ emitido pelo processo se enquadra no ciclo natural.

A gaseificação tem a grande vantagem de poder usar qualquer tipo de composto orgânico e em seu produto final sempre terá gases ricos em hidrogênio e óxidos de carbono, sendo assim um tipo de energia ecologicamente sustentável.

Utilizou-se um software para monitorar e controlar a leitura de dados da planta, além de analisar e documentar. Estes dados serviram como parâmetro de entrada para realização do controle do reator de gaseificação que utilizou um micro controlador como hardware para realização da automação, retornando assim um gaseificador otimizado.

\section{Resultados e Discussão}

Ao analisar o algoritmo, notou-se uma dificuldade de realizar a comunicação entre o software e o hardware que recebia os dados da planta de gaseificação, logo foi necessário a implantação de outros tipos de comunicação para diferentes protocolos. Ao partir do mesmo, o algoritmo ficou mais completo possibilitando uma comunicação com diferentes tipos de protocolos.

No código foi implantado dois gráficos que plotam temperatura e pressão na planta, possibilitando a verificação em tempo real destes dados. Esta implementação permite a regulação da planta, que pode ser feita acionando os motores de alimentação, assim maximizando o rendimento final tudo isso através de um interface VI do software LabView.

Após a conclusão do algoritmo, implementou-se um micro controlador Raspbarry Pi para executar o software e controlar o sistema, Com o micro controlador, obtevese como vantagens: um sistema de baixa energia; bom processamento; possibilidade de sistema embarcado; maior mobilidade e autonomia, além de se apresentar um custo financeiro bem mais em conta que uma workstation convencional

Figura 1. Diagrama do algoritmo.

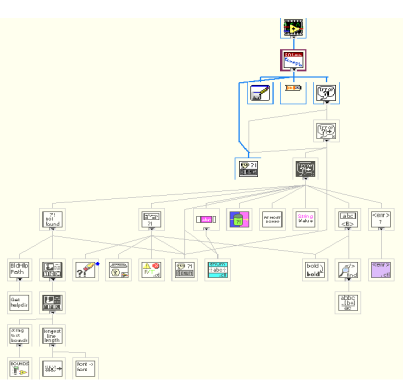

Figura 2. Interface.

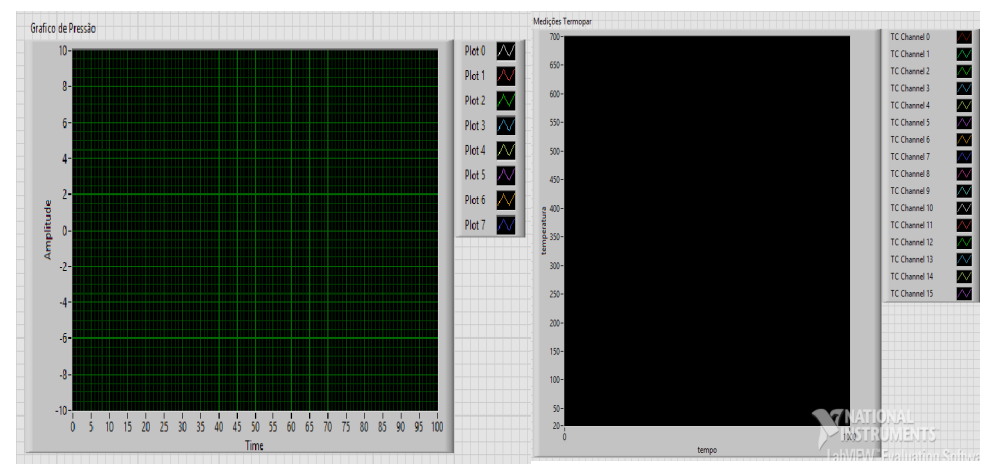

\section{Conclusões}

Conclui-se que com a implementação de um sistema controlado com uma interface simples e a utilização de um micro controlador facilita a operação em um planta e com isso há uma maximização do rendimento e uma diminuição de energia que serão possíveis de detecção em trabalhos futuros.

\section{Agradecimentos}

Agradeço pelo auxilio neste projeto ao Professor Doutor Caio Glauco Sanchez, e ao doutorando André Luiz Martelli.

SÁNCHEZ, C. G.; SANTOS, Francisco José dos ; BIZZO, Waldir Antonio; SANCHEZ, Elisabete Maria Saraiva; FERNÁNDES, Marcelo Côrtes ; BEHAINE, Jhon Jairo Ramires ; Del CAMPO, E. R. B. ; Cruz, W. C. Tecnologia da Gaseificação de biomassa. 01. ed. Campinas: Atomo, 2010. v. $01.432 \mathrm{p}$ 